\title{
PENGARUH TERAPI KOGNITIF TERHADAP HARGA DIRI REMAJA KORBAN BULLYING
}

\author{
Betie Febriana ${ }^{1}$, Sri Poeranto ${ }^{2}$, Rinik Eko Kapti ${ }^{3}$ \\ ${ }^{1}$ Fakultas IImu Keperawatan Universitas Islam Sultan Agung \\ ${ }^{2}$ Program Studi Kedokteran Fakultas Kedokteran Universitas Brawijaya \\ ${ }^{3}$ Magister Keperawatan Fakultas Kedokteran Universitas Brawijaya
}

\begin{abstract}
ABSTRAK
Bullying memberikan efek negatif pada korbannya terutama remaja. Beberapa penelitian menyebutkan efek yang paling besar adalah menurunnya harga diri korban. Studi sebelumnya menemukan bahwa harga diri rendah merupakan faktor penyebab utama yang berakibat pada buruknya performa remaja di sekolah baik prestasi maupun perilaku mereka. Oleh karena itu, dibutuhkan terapi untuk meningkatkan harga diri remaja. Penelitian ini bertujuan melihat pengaruh terapi kognitif pada perubahan harga diri remaja korban bullying. Desain pada penelitian ini adalah kuantitatif dengan True Experimental Pre-Post Test With Control Group. Jumlah sampel sebanyak 17 responden pada masing-masing kelompok dengan teknik simple random sampling.Instrument harga diri menggunakan kuesioner dari teori Stuart (2013), Kaplan (2007), dan Herdman (2015) yang dinilai dari aspek kognitif, afektif, prilaku, sosial, dan fisik. Hasil penelitian ini menunjukkan bahwa terdapat perbedaan harga diri antara sebelum dan sesudah terapi pada kelompok perlakuan (nilai $p=0,001$ ). Sedangkan, pada kelompok kontrol tidak terdapat perbedaan harga diri antara sebelum dan sesudah terapi (nilai $p=0,564$ ). Terdapat perbedaan antara kelompok kontrol dan perlakuan setelah diberikan terapi kognitif (nilai $\mathrm{P}=0,031$ ), artinya ada pengaruh pemberian terapi kognitif terhadap harga diri remaja korban bullying. Temuan lain dalam penelitian ini adalah bahwa aspek kognitif $(O R=5,25)$ merupakan aspek harga diri yang paling kuat hubungannya dengan terapi kognitif dan yang paling lemah adalah aspek sosial $(1,63)$ sehingga dibutuhkan terapi lain sebagai terapi pelengkap untuk meningkatkan aspek sosial .
\end{abstract}

Kata kunci :bullying, harga diri, terapi kognitif, remaja korban bullying.

\begin{abstract}
Bullying brings negative effects on its victims, especially in adolescents. Some studies said that the greatest effect of bullying is the reduced self-esteem of the victim. Previous studies have found that low self-esteem are the main factor that lead to poor performance in school adolescents both achievement and behavior. Therefore, treatment is required to improve the self-esteem of adolescents. This study examines the effect of cognitive therapy on self-esteem of adolescent victims of bullying. Design of this research is quantitative by using True Experimental Pre-Post Test With Control Group. The total sample is 17 respondents in each group by simple random sampling technique. The instrument of self-esteem from theory of Stuart (2013), Kaplan (2007), and Herdman (2015)based on cognitive aspect, affective, behavior, social, and physic as symptoms of self-esteem. This research shows that, there are differences in self-esteem between before and after therapy in the treatment group $(p=0.001)$. In the treatment group there was no difference between the self-esteem before and after treatment $(p=0.564)$. There is a difference between control and treatment groups after being given cognitive therapy $(P=0.031)$, in a nutshell, there is an impact of cognitive therapy to self-esteem of adolescent victims of bullying. Another finding in this study is that the cognitive aspect $(O R=5,25)$ is an aspect of self-esteem is most strongly linked to cognitive therapy and the weakest is the social aspect $(O R=1,63)$ and so we need another therapy as a complementary therapy to enhance the social aspect.
\end{abstract}

Keywords: bullying, self-esteem, cognitive therapy, adolescent victims of bullying

Jurnal IImu Keperawatan, Vol 4:, No 1. Mei 2016 ; Korespondensi : Betie Febriana. Fakultas IImu Keperawatan Universitas Islam Sultan Agung, Semarang Jl.Kaligawe Km.4, kode pos 50112. Betie.febriana@gmail.comTelp.081314774618. 


\section{PENDAHULUAN}

Remaja merupakan masa peralihan antara masa kanak-kanak dan dewasa yang rentan terhadap terjadinya masalah psikososial (Steinbeg, 2009). Salah satunya masalah tersebut adalah bullying. Bullying dapat didefinisikan sebagai sebuah pola perilaku agresif yang berulang, dengan intensi yang negatif, diarahkan dari seorang anak kepada anak yang lain yang kekuatannya yang tidak seimbang (Olweus, 1993).

Di Indonesia, data Komisi Perlindungan Anak (KPAI) menyebutkan, sejak 2012 hingga 2015, sebanyak 87 \% mengalami kasus kekerasan yang di dalamnya termasuk bullying. Hasil kajian Konsorsium Nasional Pengembangan Sekolah Karakter tahun 2014 menyebutkan, hampir setiap sekolah di Indonesia ada kasus bullying.

Perilaku bullying memberikan efek negatif terutama pada korban. Uba,dkk (2010) dalam studinya menemukan hubungan yang kuat antara harga diri dan perilaku bullying. Studi lain yang dilakukan Darney, Howcroft, dan Stroud (2013) membuktikan bahwa seseorang yang pernah mengalami bullying di sekolah sebelumnya akan berakibat pada penurunan harga diri pada masa dewasa dan setelahnya dan ini akan berakibat buruk pada kepribadian dan cara mereka menyelesaikan masalah. Salmon, James, Smith (1998) dalam studinya menyatakan bahwa harga diri merupakan aspek yang paling terpengaruh oleh perilaku bullying dibandingkan ansietas dan depresi.

Harga diri yang tinggi dan konsep diri positif adalah karakteristik penting dari kesejahteraan individu(Santrock, 2007). Menurut Taylor, Peplau dan Sears (2009), Orang dengan harga diri yang rendah akan berpikir buruk tentang diri sendiri,tidak memiliki tujuan hidup yang jelas, cenderung pesimis tentang masa depan, mengingat masa lalu mereka lebih negatif dan berkubang dalam suasana hati negatif mereka dan lebih rentan terhadap depresi ketika mereka menghadapi stress.

Selain itu, semakin rendah harga diri seseorang akan lebih berisiko terkena gangguan kepribadian. Pada beberapa penelitian mengaitkan rendahnya harga diri dengan adanya kecemasan sosial. La Greca dalam Fitria (2013) menyatakan jika orang yang memiliki harga diri yang rendah akan memiliki perasaan takut gagal ketika terlibat dalam hubungan sosial.

Penelitian yang dilakukan Simbar, Ruindungan dan Solang (2015) menyebutkan bahwa 26,7\% remaja memiliki harga diri rendah pasca mendapat perlakuan bullying yaitu menarik diri dari lingkungan sekitar untuk memperoleh rasa aman. Jika ini terus berlanjut maka akan muncul ide bunuh diri hingga percobaan bunuh diri karena perasaan malu (harga diri rendah) (Espelage\&Holt, 2012). Oleh karena itu, pencegahan dan rehabilitasi sedini mungkin 
harus segera dilaksanakan.

Lambatnya penanganan akan memperburuk kondisi (Meyer et al., 2008) karena pengalaman remaja terutama kaitannya dengan harga diri merupakan dasar untuk keberhasilan transisi mereka menjadi dewasa.

World Health Organization

menyebutkan bahwa perawat jiwa merupakan tenaga kesehatan terbesar yang tersebar di seluruh dunia yaitu sebesar 40\%. Dengan jumlah sebanyak ini diharapkan mampu memecahkan masalah kesehatan jiwa dunia termasuk masalah bullying pada remaja. Salah satu intervensi keperawatan yang dapat dilakukan oleh seorang perawat adalah terapi kognitif.

Terapi kognitif (Cognitive Therapy) adalah suatu terapi yang mengidentifikasi atau mengenali pemikiran-pemikiran yang negatif dan merusak yang dapat mendorong ke arah rendahnya harga diri dan depresi yang menetap (Allen, 2006). Pemberian terapi kognitif pada remaja yang menjadi korban bullying diharapkan dapat menstimulus remaja untuk memiliki pola pikir yang positif sehingga dapat mengatasi masalah harga diri rendah yang dialami dan meningkatkan kualitas hidupnya.

Tujuan dari penelitian ini yaitu mengetahui pengaruh terapi kognitif terhadap harga diri remaja korban bullying.

\section{METODE}

Penelitian ini merupakan penelitian kuantitatif dengan menggunakan rancangan True Experimental Pre-Post Test With Control Group. Terapi kognitif sebagai variable independen dan harga diri sebagai variabel dependen. Instrument harga diri menggunakan kuesioner dari teori Stuart (2013), Kaplan (2010), dan Herdman (2015) yang dinilai dari aspek kognitif, afektif, prilaku, sosial, dan fisik. Instrument terdiri dari 30 pertanyaan. Instrumen valid dengan nilai $r$ hitung antara 0,567-0,836 dan reliabel dengan nilai 0,957.

Terapi kognitif diberikan dalam 3 sesi yaitu sesi 1 Identifikasi pikiran otomatis negatif, sesi 2 Penggunaan tanggapan rasional terhadap pikiran otomatis negative dan sesi 3 Manfaat tanggapan rasional terhadap pikiran otomatis yang negative. Terapi dilakukan sebanyak 6 pertemuan masing-masing pertemuan dilakukan setiap minggu berkisar 45-60 menit pada masing-masing responden.

Sampel sebanyak 17 responden pada masingmasing kelompok baik kontrol ataupun perlakuan dengan metode simple random sampling. Kelompok perlkuan mendapatkan terapi kognitif sedangkan Kelompok kontrol tanpa terapi. Tempat penelitian di SMA Taman Madya Malang dengan waktu penelitian bulan Maret-Mei 2016. Analisis bivariat menggunakan ujimarginal homogeneity dan Uji Kolmogorov 
smirnov dan odd ratio untuk mengetahui keeratan hubungan tiap aspek harga diri dengan terapi kognitif.

HASIL

\section{Karakteristik responden}

Tabel 1 Karakteristik Responden Remaja Korban Bullying Di SMA Taman Madya Kelas X Dan XI Tahun 2016.

\begin{tabular}{|c|c|c|c|c|c|}
\hline \multirow[t]{2}{*}{ Variabel } & \multirow[t]{2}{*}{ Kategori } & \multicolumn{2}{|c|}{$\begin{array}{c}\text { Kelompok } \\
\text { Kontrol } \\
(\mathrm{N}=17)\end{array}$} & \multicolumn{2}{|c|}{$\begin{array}{c}\text { Kelompok } \\
\text { Perlakuan } \\
(\mathrm{N}=17)\end{array}$} \\
\hline & & $\mathrm{N}$ & $\%$ & $\mathrm{~N}$ & $\%$ \\
\hline Jenis & Laki-laki & 16 & 94,1 & 8 & 47 \\
\hline \multirow[t]{2}{*}{ kelamin } & Perempuan & 1 & 5,9 & 9 & 53 \\
\hline & Total & 17 & 100 & 17 & 100 \\
\hline \multirow{3}{*}{$\begin{array}{l}\text { Pekerjaan } \\
\text { ayah }\end{array}$} & Tidak bekerja & 0 & 0 & 1 & 5,9 \\
\hline & Bekerja & 17 & 100 & 16 & 94,1 \\
\hline & Total & 17 & 100 & 17 & 100 \\
\hline \multirow{3}{*}{$\begin{array}{l}\text { Pekerjaan } \\
\text { ibu }\end{array}$} & Tidak bekerja & 8 & 47 & 6 & 35,3 \\
\hline & Bekerja & 9 & 53 & 11 & 64,7 \\
\hline & Total & 17 & 100 & 17 & 100 \\
\hline \multirow{6}{*}{$\begin{array}{l}\text { Pendidikan } \\
\text { ayah }\end{array}$} & Tidak sekolah & 0 & 0 & 0 & 0 \\
\hline & SD & 2 & 11,7 & 1 & 5,8 \\
\hline & SMP & 5 & 29,5 & 1 & 5,8 \\
\hline & SMA & 7 & 42,2 & 13 & 76,7 \\
\hline & Perguruan Tinggi & 3 & 17,6 & 2 & 11,7 \\
\hline & Total & 17 & 100 & 17 & 100 \\
\hline \multirow{6}{*}{$\begin{array}{l}\text { Pendidikan } \\
\text { ibu }\end{array}$} & Tidak sekolah & 0 & 0 & 0 & 0 \\
\hline & SD & 4 & 23,5 & 4 & 23,5 \\
\hline & SMP & 2 & 11,8 & 2 & 11,8 \\
\hline & SMA & 10 & 58,9 & 7 & 41,2 \\
\hline & Perguruan Tinggi & 1 & 5,8 & 4 & 23,5 \\
\hline & Total & 17 & 100 & 17 & 100 \\
\hline \multirow[t]{3}{*}{ Prestasi } & Tidak ada & 10 & 58,8 & 7 & 41,2 \\
\hline & Ada & 7 & 41,2 & 10 & 58,8 \\
\hline & Total & 17 & 100 & 17 & 100 \\
\hline \multirow[t]{3}{*}{ Fisik } & Tidak puas & 5 & 29,4 & 6 & 35,3 \\
\hline & Puas & 12 & 71,6 & 11 & 64,7 \\
\hline & Total & 17 & 100 & 17 & 100 \\
\hline \multirow[t]{3}{*}{ Pola asuh } & Tidak Baik & 11 & 64,7 & 5 & 29,4 \\
\hline & Baik & 6 & 35,3 & 12 & 70,6 \\
\hline & Total & 17 & 100 & 17 & 100 \\
\hline
\end{tabular}

Sumber : Data primer diolah, 2016

Perbedaan harga diri remaja korban bullying sebelum dan sesudah diberikan terapi kognitif pada kelompok perlakuan.
Tabel 2 Hasil Uji Marginal Homogeneity Harga Diri Remaja Korban Bullying Sebelum Dan Sesudah Diberikan Terapi Kognitif Pada Kelompok Perlakuan

\begin{tabular}{|c|c|c|c|c|c|c|c|}
\hline & & \multicolumn{4}{|c|}{ Harga diri setelah terapi } & \multirow[t]{3}{*}{ Total } & \multirow[t]{3}{*}{$p$} \\
\hline & & Rendah & Sedang & Cukup & Tinggi & & \\
\hline & & & & Tinggi & & & \\
\hline Harga & Rendah & 0 & 4 & 0 & 0 & 4 & 0,001 \\
\hline diri & Sedang & 0 & 0 & 5 & 0 & 5 & \\
\hline \multirow{3}{*}{$\begin{array}{l}\text { sebelum } \\
\text { terapi }\end{array}$} & Cukup & 0 & 0 & 3 & 3 & 6 & \\
\hline & tinggi & & & & & & \\
\hline & Tinggi & 0 & 0 & 0 & 2 & 2 & \\
\hline Total & & 0 & 4 & 8 & 5 & 17 & \\
\hline
\end{tabular}
terdapat perubahan kategori harga diri pada kelompok perlakuan. Harga diri rendah setelah terapi meningkat menjadi harga diri sedang pada 4 orang responden, harga diri sedang meningkat menjadi harga diri cukup tinggi pada 5 orang responden dan harga diri cukup tinggi menjadi tinggi sebanyak 3 orang.

Perbedaan harga diri remaja korban bullying sebelum dan sesudah diberikan terapi kognitif pada kelompok kontrol.

Tabel 3 Hasil Uji Marginal Homogeneity Beda Harga Diri Remaja Korban Bullying Sebelum Dan Sesudah Diberikan Terapi Kognitif Pada Kelompok Kontrol

\begin{tabular}{llcccccc}
\hline & & \multicolumn{3}{l}{ Harga diri setelah terapi } & \multicolumn{2}{c}{ Total $p$} \\
\cline { 3 - 7 } & & Rendah & Sedang & $\begin{array}{c}\text { Cukup } \\
\text { Tinggi }\end{array}$ & Tinggi & & \\
\hline Harga & Rendah & 3 & 1 & 0 & 0 & 4 & 0,564 \\
diri & Sedang & 0 & 5 & 1 & 0 & 6 & \\
sebelum & Cukup & 0 & 0 & 5 & 0 & 5 & \\
terapi & tinggi & & & & & & \\
& Tinggi & 0 & 0 & 1 & 1 & 2 & \\
\hline Total & & 3 & 6 & 7 & 1 & 17 & \\
\hline
\end{tabular}

Berdasarkan tabel 3 didapatkan bahwa harga diri rendah pada responden setelah terapi 
tetap menjadi harga diri rendah pada 3 orang responden, hanya 1 orang yang meningkat menjadi harga diri sedang.

Harga diri sedang tetap menjadi harga diri sedang pada 5 orang responden dan meningkat pada 1 responden menjadi harga diri cukup tinggi. Harga diri cukup tinggi tetap pada kategori tersebut sebanyak 5 orang. Sedangkan kategori tinggi berada tetap pada kategori cukup tinggi sebanyak 1 orang dan juga mengalami penurunan menjadi kategori cukup tinggi pada 1 orang responden.

Perbedaan harga diri remaja korban bullying sesudah diberikan terapi kognitif pada kelompok perlakuan dan kontrol di SMA Taman Madya, Malang Kelas X Dan XI Tahun 2016.

Tabel 4 Hasil Uji Kolmogorov-Smirnov Perbedaan Harga Diri Remaja Korban Bullying Sebelum Diberikan Terapi Kognitif Pada Kelompok Perlakuan Dan Kontrol

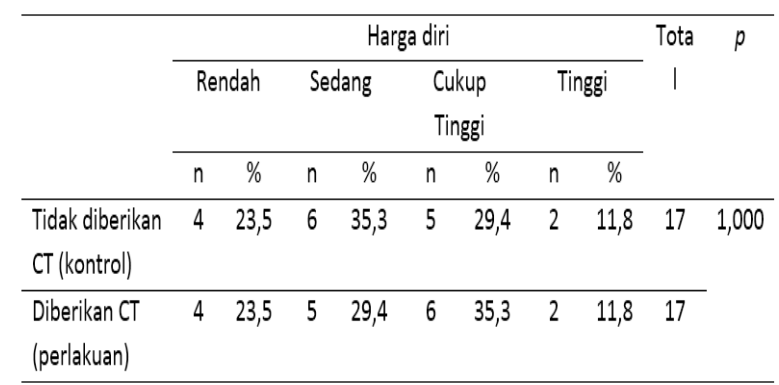

Berdasarkan hasil ujikolmogorov-smirnov pada tabel 4 didapatkan bahwa nilai $p$ adalah 1,000 $(p>0,05)$ yang artinya tidak ada perbedaan harga diri antara kelompok kontrol dan kelompok perlakuan sebelum diberikan terapi pada kelompok perlakuan.

Tabel 5 Hasil Uji Kolmogorov-Smirnov Perbedaan Harga Diri Remaja Korban Bullying Setelah Diberikan Terapi Kognitif Pada Kelompok Perlakuan Dan Kontrol

\begin{tabular}{|c|c|c|c|c|c|c|c|c|c|c|}
\hline & \multicolumn{8}{|c|}{ Harga diri } & \multirow{4}{*}{$\begin{array}{c}\text { Tota } \\
\text { I }\end{array}$} & \multirow[t]{4}{*}{$p$} \\
\hline & \multirow{2}{*}{\multicolumn{2}{|c|}{ Rendah }} & \multirow{2}{*}{\multicolumn{2}{|c|}{ Sedang }} & \multirow{2}{*}{\multicolumn{2}{|c|}{$\begin{array}{l}\text { Cukup } \\
\text { Tinggi }\end{array}$}} & \multirow{2}{*}{\multicolumn{2}{|c|}{ Tinggi }} & & \\
\hline & & & & & & & & & & \\
\hline & $n$ & $\%$ & $n$ & $\%$ & $n$ & $\%$ & $\mathrm{n}$ & $\%$ & & \\
\hline $\begin{array}{l}\text { Tidak diberikan } \\
\text { CT (kontrol) }\end{array}$ & 3 & 17,6 & 6 & 35,3 & 7 & 41,2 & 1 & 5,9 & 17 & 0,031 \\
\hline $\begin{array}{l}\text { Diberikan CT } \\
\text { (perlakuan) }\end{array}$ & 0 & 0 & 4 & 23,5 & 8 & 47,1 & 5 & 29,4 & 17 & \\
\hline
\end{tabular}

Berdasarkan hasil uji kolmogorov-smirnov pada tabel 5 didapatkan bahwa nilai $p$ adalah 0,031 $(p<0,05)$ yang artinya terdapat perbedaan harga diri setelah diberikan terapi pada kelompok perlakuan dan kontrol. Oleh karena itu, dapat disimpulkan bahwa ada pengaruh antara pemberian terapi kognitif dengan harga diri.

Sedangkan kekuatan hubungan dilihat dari Odd Ratio (OR) antara terapi kognitif dan aspek yang ada dalam harga diri karena desain yang digunakan adalah kasuskontrol. Berikut penyajiannya.

Tabel 6 Kekuatan Hubungan Aspek Harga Diri Terhadap Terapi Kognitif

\begin{tabular}{lcccc}
\hline \multicolumn{1}{c}{ Aspek } & $\begin{array}{c}\text { Odd } \\
\text { Ratio(OR) }\end{array}$ & $\begin{array}{c}\text { Probabilitas (p) } \\
\text { lower }\end{array}$ & \multicolumn{2}{c}{ IK 95\% } \\
& & & & \\
\hline Kognitif & 5,250 & 84 & 1,093 & 25,211 \\
Afektif & 2,619 & 72 & 0,655 & 10,478 \\
Prilaku & 2,545 & 71 & 0,516 & 12,546 \\
Fisik & 2,133 & 68 & 0,519 & 8,761 \\
Sosial & 1,630 & 62 & 0,411 & 6,459 \\
\hline
\end{tabular}




\section{PEMBAHASAN}

\section{Perbedaan harga diri remaja korban bullying} sebelum dan sesudah diberikan terapi kognitif pada kelompok perlakuan di SMA Taman Madya, Malang Kelas X Dan XI Tahun 2016

Hasil penelitian memperlihatkan bahwa setelah mendapatkan terapi kognitif menunjukkan adanya peningkatan harga diri antara sebelum dan sesudah pada kelompok perlakuan yaitu semua responden (100\%) yang terkategori harga diri rendah setelah terapi berada di kategori harga diri sedang (tabel 2). Hasil akumulasi, sebanyak 12 dari 17 remaja (70,6\%) mengalami peningkatan harga diri. Hal ini berarti terdapat perubahan tanda dan gejala harga diri ke arah positif meskipun masih dalam kategori yang sama. Dapat disimpulkan bahwa terjadi perubahan harga diri pada remaja korban bullying setelah diberikan terapi kognitif pada kelompok perlakuan.

Hasil analisis bivariat dengan menggunakan uji marginal homogeneity pada tabel 4 didapatkan hasil $p$-value 0,001 dimana $p$ value $<0,05$. Hal ini berarti ada perbedaan harga diri pada kelompok perlakuan sebelum dan sesudah pemberian terapi kognitif.

Hasil ini selaras dengan studi yang dilakukan oleh Ingul et al. (2013) yang membuktikan bahwa terapi kognitif memberikan efek lebih besar dalam mengurangi gejala dan memperbaiki kondisi remaja dengan fobia sosial yang berpengaruh terhadap harga dirinya

Remaja yang menjadi korban bullying akan menterjemahkan pengalaman bullying dalam kehidupan sehari-hari. Penterjemahan ini dimulai dari memikirkan apa yang telah terjadi sehingga timbul asumsi, ketika asumsi tersebut terus berulang maka akan mengaktifkan asumsi buruk yang akan menghasilkan pikiran otomatis negatif dan akhirnya diterjemahkan melalui perasaan, pikiran, perilaku baik intrapersonal ataupun interpersonal ( Power, 2010).

Pikiran otomatis negatif merupakan respon yang terjadi dengan cepat terhadap situasi dan tanpa analisis rasional, biasanya sering bersifat negatif dan berdasarkan logika yang keliru (Beck, 2009).

Dari sesi terapi teridentifikasi pikiran otomatis negatif dari responden korban bullying antara lain merasa dirinya bodoh, merasa tidak bisa melakukan apapun karena selalu dinilai salah, merasa diawasi oleh teman sekitar dan diperbincangkan, setiap ada 2 orang atau lebih yang berkumpul pasti sedang membicarakan dirinya, merasa tidak berguna, merasa tidak beruntung, tidak dihargai dan dihormati, berfikir bahwa dirinya memang seperti apa yang diolokkan temannya, merasa tidak disukai teman. Pikiran otomatis negatif yang dihasilkan korban bullying ini menghasilkan perilaku maladaptif yang mengarah kepada harga diri 
rendah. Hal ini sejalan dengan studi yang dilakukan oleh (Waite, dkk, 2012) bahwa korban bullying akan merasa tidak nyaman di suatu lingkungan sehingga dia cenderung akan menghindar dan jika terus menerus dilakukan akan mempengaruhi harga dirinya.

Terapis membantu klien mengidentifikasi pikiran otomatis negatif yang berpengaruh terhadap harga diri, menggali pikiran tersebut, mengevaluasi kembali kondisi yang realistis, serta mengganti pikiran negatif yang diungkapkan dengan hal yang positif berdasarkan pengalaman responden selama ini. Selama restrukturisasi pikiran, terapis memberikan terapi kognitif yang terdiri dari 3 sesi yang dilaksanakan dalam 6 minggu pertemuan yang dilakukan setiap minggu.

Sejalan dengan studiChatteron,dkk (2007) dalam penelitiannya tentang terapi kognitif pada harga diri seorang wanita yang berfikir untuk bunuh diri, skor akhir memperlihatkan peningkatan yang signifikan yaitu setelah diberikan terapi kognitif 6 pertemuan. Dalam penelitiannya Hall dan Terrier berkesimpulan bahwa terapi kognitif ini memakai pendekatan kepada klien yang berfokus pada masalah dan pikiran otomatis negatifnya.

Di sesi akhir terapis berdiskusi tentang manfaat berfikir positif dan bagaimana manfaat latihan selama ini sehingga diharapkan responden akan menyadari pentingnya mengontrol pikiran negatif dan dilakukan terus jika pikiran otomatis negatif muncul. Kesadaran akan pentingnya suatu hal dilakukan merupakan modal perubahan seseorang ke arah yang lebih baik (Harter, 2006). Allen (2006) mengataan bahwa latihan kognitif yang dilakukan responden akan meningkatkan kemampuan mengontrol pikiran otomatis negatif.

Terapi diberikan secara individu sehingga responden dapat lebih leluasa mengeksplorasi perasaan dan pikiran yang dimiliki selama ini terkait bullying. Beberapa penelitian menyebutkan bahwa terapi yang dilaksanakan secara individu lebih efektif daripada berkelompok (Ingul, 2013; Mortberg, 2007; Stangier, 2003). Hal ini terjadi karena karena lebih terjaga secara privasi. Terapi dilakukan di ruang tertutup sehingga di ruangan hanya ada terapis dan satu responden saja setiap kali terapi dilakukan.

Hasil penelitian ini sejalan dengan penelitian yang dilakukan Kristiyaningsih (2009) tentang pengaruh terapi kognitif terhadap perubahan harga diri rendah dan kondisi depresi pasien gagal ginjal kronik menghasilkan kesimpulan bahwa terdapat perubahan bermakna terhadap rata-rata tingkat harga diri dan kondisi pasien. Temuan yang lain, pada remaja perempuan yang memiliki masalah berat badan (obesitas) di Prancis terapi kognitif dinilai efektif untuk meningkatkan harga diri mereka ( Fossati, 2004). 
Meskipun skor akhir pada responden belum semua mencapai kategori harga diri tinggi tetapi sudah menunjukkan hasil yang cukup bermakna dalam meningkatkan harga diri remaja korban bullying . Dapat peneliti asumsikan bahwa harga diri remaja korban bullying akan dapat terus meningkat jika terapi kognitif yang telah dilatih pada mereka terusmenerus diterapkan secara mandiri.

\section{Perbedaan harga diri remaja korban bullying} sebelum dan sesudah diberikan terapi kognitif pada kelompok perlakuan di SMA Taman Madya, Malang Kelas X Dan XI Tahun 2016

Kelompok kontrol pada penelitian ini tidak mendapatkan intervensi terapi kognitif selama penelitian dan hasil yang didapatkan adalah bahwa secara statistik, responden terbanyak berada dalam kategori yang sama dengan sebelum dilakukan intervensi. Namun, skor harga diri sebagian besar responden $(76,5 \%)$ pada kelompok ini mengalami peningkatan yang artinya harga dirinya semakin menurun.

Berdasarkan hasil analisi menggunakan uji marginal homogeneity pada tabel 3 didapatkan hasil $p$-value 0,564 dimana $p>0,05$ yang berarti tidak ada perbedaan harga diri pada kelompok kontrol antar sebelum dan sesudah intervensi yaitu terapi kognitif.
Pada kelompok kontrol setelah intervensi lebih banyak mengalami penurunan harga diri, selain karena tidak diberikannya intervensi apapun juga karena ,responden terus menerus terpapar dengan bullying dan responden juga tidak tahu mekanisme koping yang harus dilakukan jika mendapatkan perlakuan bullying yang bisa digunakan untuk mengurangi tanda dan gejala penurunan harga diri. Penyebab lainnya bahwa bullying pun akan memunculkan banyak stressor yang menambah parah dampaknya seperti interaksi yang tidak harmonis, munculnya kelompok-kelompok siswa (geng), tidak adanya gairah pada kegiatan produktif karena responden berada dalam satu kelompok dengan pelaku bullying.

Beberapa responden menganggap tidak bisa mempercayai siapapun untuk menjadi teman bercerita (curhat) termasuk kepada guru. Hal ini seperti yang dikemukakan oleh Hurlock (2012) bahwa pendampingan remaja baik oleh orang tua dan guru di masa sekolah tingkat atas paling besar dibutuhkan dibandingkan masa usia yang lain, karena usia ini merupakan puncak pembentukan kepribadian dari seseorang. Hasil studi Patchin dan Hinduja (2010) harga diri rendah adalah faktor penyebab utama $(47,4 \%)$ dari semua masalah remaja yang secara langsung ataupun tidak langsung berakibat pada performa remaja di sekolah baik prestasi maupun perilaku mereka. 
Ketidakmampuan meningkatkan harga diri akan menyebabkan semakin buruknya kehidupan remaja di sekolah. Sehingga dapat disimpulkan bahwa harga diri remaja semakin menurun karena tidak ada intervensi untuk memperbaiki pikiran otomatis negatif yang muncul karena bullying.

\section{Perbedaan harga diri sesudah diberikan terapi} kognitif pada kelompok perlakuan dan kontrol.

Hasil ujikolmogorov-smirnov pada tabel 5 didapatkan bahwa nilai $p$ adalah $0,031(p<0,05)$ sehingga dapat disimpulkan bahwa ada pengaruh pemberian CT dengan harga diri remaja korban bullying.

Kelompok perlakuan mendapatkan intervensi berupa terapi kognitif . Varcarolis, dkk (2006) menjelaskan bahwa terapi kognitif merupakan terapi yang didasarkan pada kesalahan berfikir klien dengan muncul pikiran otomatis negatif, mendorong pada penilaian negatif terhadap diri sendiri dan orang lain.

Terapi kognitif mampu meningkatkan fungsi kognitif responden. Responden diajarkan untuk meningkatkan kemampuan berfikir logis terhadap pikiran otomatis negatif dan menghadirkan persepsi positif dari pikiran negatif yang muncul.Hal ini sejalan dengan penelitian Pasaribu (2012) merekomendasikan terapi kognitif untuk mengontrol pikiran negatif pasien kanker di RS Dharmais Jakarta.

Harter (2006) menjelaskan tingginya harga diri diasosiasikan dengan pembentukan strategi koping yang baik, tingginya motivasi, serta emosi secara positif. Pemberian terapi kognitif mampu merubah pikiran-pikiran negatif pada remaja korban bullying menjadi pikiran yang lebih positif dan perilaku maladaptif menjadi efektif sesuai dengan kemampuan yang dimiliki sehingga kualitas hidup yang baik akan tercapai.

Hasil penelitian menunjukkan bahwa terjadi perbedaan harga diri antara kelompok kontrol dan perlakuan. Penelitian ini selaras dengan hasil studi Farahmand, dkk (2014) yang menemukan bahwa terjadi peningkatan harga diri yang signifikan pada pasien depresif dibandingkan dengan kelompok kontrol setelah diintervensi dengan terapi kognitif di Iran. Temuan lain pada remaja perempuan yang memiliki masalah berat badan (obesitas) di Prancis terapi kognitif dinilai efektif untuk meningkatkan harga diri mereka ( Fossati, 2004).Oleh karena itu, dapat disimpulkan bahwa terapi kognitif dapat mempengaruhi harga diri remaja korban bullying ke arah positif.

Tanda dan gejala harga diri dalam penelitian ini dilihat dari aspek kognitif, perilaku, afek, fisik, dan sosial. Dari hasil analisis, didapatkan bahwa 
aspek yang paling berpengaruh setelah diintervensi dengan terapi kognitif adalah aspek kognitif.

Clement (2012) mengungkapkan bahwa pemikiran (kognitif) mempunyai efek yang sangat besar terhadap emosi dan perilaku. Dengan merubah pikiran yang buruk/tidak tepat/pikiran negatif, seseorang dapat merubah reaksi terhadap kondisi tertentu dan mengintrepretasikan makna dari peristiwa berdasarkan yang dia pikirkan. Sejalan dengan penelitian ini bahwa aspek yang lain seperti perilaku, afektif, fisik dan sosial pun aspek yang terpengaruh terapi kognitif dilihat dari kekuatan hubungannya dengan terapi kognitif. Selaras dengan apa yang disampaikan Power (2010) bahwa 4 aspek yang berubah dengan terapi kognitif yaitu kognitif, perilaku, fisik dan afektif, dalam penelitian ini kognitif paling menonjol tetapi aspek lain pun mempunyai kekuatan hubungan walaupun tidak sebesar aspek kognitif.

\section{DAFTAR PUSTAKA}

Allen. N.B. (2006). An Introduction To The Psychotherapies $4^{\text {th }}$ Ed. Editor Sidney Bloch. Oxford University Press: New York

Beck, A. T. (2009). Cognitive therapy of depression $\left(5^{T H}\right.$ ed) . New York: Guilford.

Chatterton, L. Hall, P. dan Tarrier, N. (2007). Cognitive Therapy for Low Self-Esteem in the Treatment of Depression in an

\section{KESIMPULAN}

Studi ini menunjukkan bahwa terapi kognitif mampu memberikan dampak bagi peningkatan harga diri korban bullying di kalangan remaja. Terdapat pengaruh terapi kognitif terhadap harga diri remaja korban bullying dengan nilai $\mathrm{p}$ 0,031 .

Hasil dari penelitian ini menunjukkan bahwa penting ini untuk mengembangkan dan mengaplikasikan pemberian asuhan keperawatan jiwa pada seluruh tatanan pelayanan kesehatan dengan terapi kognitif untuk remaja korban bullying untuk meningkatkan harga dirinya. Perlu dikembangkan penelitian lanjutan sebagai model terapi yang dikolaborasikan dengan terapi kognitif untuk meningkatkan harga diri pada aspek sosial yang kekuatan hubungannya paling lemah, yaitu dengan terapi ketrampilan sosial (social skill training).

Older Adult. Behavioural and Cognitive Psychotherapy, 35, 365-369. doi:10.1017/S1352465807003608 dari http://journals.cambridge.org/action/di splayAbstract? fromPage $=$ online $\&$ aid $=99$ 5204

Clément, S., Tonini, A., Khatir, F., Schiaratura, L., \& Samson, S. (2012). Short and longer term effects of musical intervention in severe Alzheimer's disease. Music Perception, 29(5), 533541 
Darney, c., Howcroft, g. \& Stroud, I. (2013).the impact that bullying at school has on an has on an individual's self-esteem during young adulthood. International journal of education and research. 1, 8, 232-230. Dari http://www.ijern.com/journal/August -2013/02.pdf

Espelage \& Holt. (2012). Suicidal Ideation and School Bullying Experiences After Controlling for Depression and Delinquency. Journal of adolescent health. 53 (2013) 27-31. Dari http://www.ncbi.nlm.nih.gov/pubmed /23790197

Fitria, I., Brouwer, R. J., Khan, S.U.R., Almigo, N. (2013). Does Self-esteem Contribute Any Effect to Social anxiety among International University Students. Malaysian Journal of Research. Vol. 01 No. $1 \mathrm{Hal}: 10-19$

Farahmand V, Hassanzadeh R, Mirzaian B, Fayyazi, Bordbar MR, Feizi J. (2014) The efficacy of group metacognitive therapy on self-esteem and mental health of patients suffering from major depressive disorder. Iran Journal Psychiatry Behavior Sci 2014; 8(2): 4-10. Dari

http://www.ncbi.nlm.nih.gov/pmc/articl es/PMC4105599/

Fossati, M., rieker,A\& golay. (2004). Therapie cognitive en groupe de l'estime de soi chez de patients obezes. Aftcc, paris .Journal de therapy comportementale et cognitive. 14:1, 29-34. Dari

http://www.pmse.ch/wpcontent/uploads/2014/01/OBESITETherapie-cognitive-en-groupe-2004.pdf

Harter, S. (2006). The development of selfrepresentations in childhood and adolescence $\left(6^{\text {th }}\right.$ ed.). New York:Wiley

Herdman, T.H. (2015). Diagnosa Keperawatan Definisi dan Klasifikasi, 2015-2017. $10^{\text {th }}$ ed. Jakarta : EGC.
Hurlock, E. B. (2012). Psikologi perkembangan : suatu pendekatan sepanjang rentang kehidupan. Surabaya : Erlangga.

Ingul, J.M, Aune, \& Nordahl. (2013). A Randomized Controlled Trial of Individual Cognitive Therapy, Group Cognitive Behaviour Therapy and Attentional Placebo for Adolescent Social Phobia. Psychother Psychosom Journal 2014;83:54-61. DOI: 0.1159/000354672. Dari http://www.ncbi.nlm.nih.gov/pubmed $/ 24281563$

Kaplan, H.I.\& Sadock,B.J. (2010). Sinopsis psikiatri. Edisi Ketujuh. Jakarta : Binarupa Aksara.

Komisi Perlindungan Anak Indonesia. (2013). Sidang HAM ke-2; Membongkar kekerasan. Retrieved 3rd September, 2014, from www.kpai.go.id

Kristyaningsih, F., Keliat, B. A. dan Helena,. N. C. D. (2009): Pengaruh Terapi Kognitif terhadap Perubahan Harga Diri dan Kondisi Depresi Pasien Gagal Ginjal Kronik di Ruang Haemodialisa RSUP Fatmawati Jakarta. Dari http://lib.ui.ac.id/file?file=digital/1255 07-TESIS0619\%20Tja\%20N09p-

Pengaruh\%20Terapi-Abstrak.pdf

Meyer-Adams, Nancy, \& Conner, Br T. (2008). School Violence: Bullying Behaviors and the Psychosocial School Environment in Middle Schools. Children \& Schools, 30(4), 211-221. Dari

http://cs.oxfordjournals.org/content/ 30/4/211.abstract

Mortberg E, Clark DM, Sundin O, Wistedt AA. (2007). Intensive group cognitive treatment and individual cognitive herapy vs. treatment as usual in social phobia: a randomized controlled trial. Acta Psychiatric Scandinavian Journal; 115: 142-154. Dari http://www.ncbi.nlm.nih.gov/pubmed/ 17244178 
Olweus, D. (1993). Bullying at school. Oxford : Blackwell Publishing

Pasaribu, J. (2012). Pengaruh terapi kognitif dan terapi penghentian pikiran terhadap perubahan ansietas, depresi, dan kemampuan mengontrol pikiran negative klien kanker di RS kanker Dharmais, Jakarta. Universitas Indonesia. http://lib.ui.ac.id/file?file=digital/20308 273-T31060-Pengaruh\%20terapi.pdf

Patchin,J. dan Hinduja, S. (2010). Cyberbullying and Self-Esteem. Journal of school health . 80(12): 615-621. Dari http://onlinelibrary.wiley.com/doi/10.1 111/j.1746-1561.2010.00548.x

Power. (2010). Emotion-Focused Cognitive Therapy. John Wiley: Oxford Malden

Salmon, james, smith. (1998). Bullying in schools: self reported anxiety, depression, and self esteem in secondary school children. BMJ. 3;317(7163):924-5. Dari http://www.bmj.com/content/317/716 3/924

Santrock,J.W. (2007). Life-Span Development. (9th Ed). NY: McGraw-Hill.

Simbar, Ruindungan, \&Solang. (2015). Analisis mengenai harga diri korban bullying (studi pada siswa korban bullying di sma nasional kawangkoan dan smk kristen kawangkoan). Jurnal Fakultas IImu Pendidikan (JFIP) Vol 3, No 1 (2015) diakses dari id.portalgaruda.org 17 Januari 2016

Stangier U, Heidenreich T, Peitz M, Lauterbach, Clark DM. (2003). Cognitive therapy for social phobia: individual versus group treatment.Behav Res Ther; 41: 9911007. http://www.ncbi.nlm.nih.gov/pubmed/ 12914803

Steinberg, L. (2012). Parenting Adolescents. Recent developments in our understanding of parenting: Bidirectional effects, causal models, and the search for parsimony. In M. H. Bornstein (Ed). Handbook of Parenting (2nd ed., pp. 103-133). New York: Erlbaum.

Stuart, G. W. (2013). Principle and practice of psychiatric nursing (10th ed.). Missouri: Mosby.

Taylor, S.E., Peplau, L.A., \& Sears, D.O. (2009). Social Psychology. (12th Ed). London: Pearson Prentice Hall.

Uba,I., yaacob, NS., juhari, R., thalib, MA. (2010). Effect of self-esteem on the relationship between depression and bullying among teenagers in malaysia. Asian social science. 6,12. Issn 19112025 (online). Dari http://www.ccsenet.org/journal/index.p hp/ass/article/view/6759

Varcarolis, E.M., Carson, V.B., dan Shoemaker, N.C. (2006). Foundations of Psychiatric Mental Health Nursing: A Clinical Approach. ( $5^{\text {th }}$ ed). St. Louis: Saunders Elsevier.

Waite, McManus, Shafran. (2012). Cognitive therapy for low self-esteem: a preliminary randomized controlled trial in a primary care setting.Journal of Behavior Therapy and Experimental Psychiatry. 43(4):1049-1057. doi: 10.1016/j.jbtep.2012.04.006.dari http://www.sciencedirect.com/science/ article/pii/S0005791612000407 